\title{
Perhitungan Kebisingan pada Rumah Sakit dan Sekolah Akibat Arus Lalu Lintas di Jalan L.L. R.E. Martadinata Kota Bandung
}

\section{HERU SANJAYA¹, PERTIWI SUPRIYANI², ANGGA MARDITAMA SULTAN SUFANIR ${ }^{3}$}

\author{
1,2Alumni Jurusan Teknik Sipil, Politeknik Negeri Bandung, Bandung 40012 \\ Email: heru.sanjaya.06121995@gmail.com; p.supriyani@yahoo.com \\ ${ }^{3}$ Dosen Jurusan Teknik Sipil, Politeknik Negeri Bandung, Bandung 40012 \\ Email: angga.mss@polban.ac.id
}

\begin{abstract}
ABSTRAK
Peningkatan volume kendaraanberdampak terhadappeningkatan kebisingan lalu lintas yang menimbulkangangguan pendengaran bagi pengguna jalan dan masyarakat disekitarnya.Tujuan penelitian ini yaitumenghitung kebisingan pada kawasan rumah sakit dan sekolah akibat arus lalu lintas di Jalan L.L. R.E. Martadinata Kota Bandung dengan menggunakan Metode Bina Marga Pd.T-10-2004-B tentang Prediksi Kebisingan Akibat Lalu Lintas dengan ModelCalculation of Road Traffic Noise (CoRTN).Dari hasil perhitungan diperoleh tingkat kebisingan di kawasan RSIA Limijati sebesar 62,46 dBA (weekdays) dan 62,01 dBA (weekend), sedangkan tingkat kebisingan dikawasan Sekolah Taruna Bakti sebesar 66,06 dBA (weekdays) dan 66,21 dBA (weekend). Dapat disimpulkan bahwa tingkat kebisingan di kawasan RSIA Limijati dan Sekolah Taruna Bakti sudah melebihi baku mutu yang diijinkan menurut Keputusan Menteri Negara Lingkungan Hidup No. 48/MENLH/11/1996 yaitu sebesar 55 dBA, sehingga untuk menurunkan tingkat kebisingan perlu dilakukan mitigasi dampak kebisingan akibat lalu lintas jalan.
\end{abstract}

Kata kunci: kebisingan pada kawasan rumah sakit, kebisingan pada kawasan sekolah, ModelCalculation of Road Traffic Noise

\begin{abstract}
The increase ofvehicle volume is impacted to the increase of traffic noise which is The increase ofvehicle volume is impacted to the increase of traffic noise which is caused sense of hearing interruptionto the road user, pedestrian, and the society in that area. This research's purpose is to calculate the traffic noise in hospital and school area which is caused by the traffic in Jalan L.L. R.E. Martadinata, Kota Bandung. The method used is Bina Marga Pd.T-10-2004-B about The Prediction of Noise caused by Traffic using Calculation of Road Traffic Noise (CORTN) Model. Based on the calculation, the number of traffic noise in RSIA Limijati area for about 62,46 dBA (weekdays) and 62,01 dBA (weekend), while Taruna Bakti School for about 66,06 dBA (weekdays) and 66,21 dBA (weekend).In conclusion, the number of traffic noise in RSIA Limijati and Taruna Bakti School area exceed the standard grade permission from Keputuan Menteri Negara Lingkungan Hidup No. 48/MENLH/11/1996 is about 55 dBA. For decreasing the number of traffic noise, it is a must for doing mitigation toward the effect of noise which is caused by traffic.
\end{abstract}

Keywords: The traffic noise in hospital area, the traffic noise in school, Calculation of Road Traffic Noise Model 


\section{PENDAHULUAN}

Peningkatan volume kendaraan berdampak terhadap peningkatan kebisingan lalu lintas yang menimbulkan gangguan pendengaran bagi pengguna jalan dan masyarakat di sekitarnya. Menurut Griefahn B. et al. (2000), kebisingan lalu lintas adalah bunyi yang tidak diinginkan dari lalu lintas kendaraan bermotor dalam tingkat dan waktu tertentu yang dapat menimbulkan gangguan kesehatan manusia dan kenyamanan lingkungan. Kebisingan lalu lintas telah menjadi faktor lingkungan yang sangat penting di kota-kota, tetapi terkadang kurang terperhatikan pengaruhnya sehingga pemecahan masalah pada hal ini kurang diperhatikan.

Kebisingan dapat diklasifikasikan berdasarkan asal sumber bising, yaitu: kebisingan yang tidak secara terus-menerus/ impulsif, kebisingan yang secara terus-menerus dalam waktu yang cukup lama/ continue, dan kebisingan yang hanya sekejap/ intermittent (Wardhana, 1999). Sumber bising terbagi menjadi sumber statis dan sumber dinamis. Sumber statis berasal dari sumber suara yang tidak bergerak, sedangkan sumber garis berasal dari sumber suara yang bergerak dan menyebar di udara (Suroto W., 2010). Kebisingan lalu lintas termasuk ke dalam jenis kebisingan intermittent dengan sumber bising dinamis.

Penggolongan jenis kendaraan menurut Manual Kapasitas Jalan Indonesia 1997 terdiri dari kendaraan ringan, kendaraan berat, dan sepeda motor. Masing-masing golongan kendaraan mempunyai berat kendaraan dan tingkat kebisingan yang berbeda-beda. Selain komposisi lalu lintas, kecepatan rata-rata kendaraan juga berpengaruh terhadap tingkat kebisingan. Faktor-faktor yang menimbulkan suara bising pada kendaraan bermotor, diantaranya: mesin kendaraan, jenis motor bakar, jenis kipas pendingin, sistem pembuangan gas sisa, hisapan dari karburator, jenis ban standar atau radial, dan bentuk kendaraan (Widyantoro, 2011).

Tingkat kebisingan adalah ukuran energi bunyi yang dinyatakan dalam satuan desibel yang disingkat dB (Keputusan Menteri Negara Lingkungan Hidup, 1996). Jenis karakter respon frekuensi dibagi menjadi tiga skala pengukuran, yaitu: skala A, B, dan C. Skala A merupakan yang paling mewakili batasan pendengaran manusia dan respon telinga terhadap kebisingan, termasuk kebisingan yang dapat menimbulkan gangguan pendengaran. Skala A tersebut dinyatakan dalam satuan dBA (Djalante, 2010).

Tujuan penelitian ini yaitumenghitung kebisingan pada kawasan rumah sakit dan sekolah akibat arus lalu lintas di Jalan L.L. R.E. Martadinata Kota Bandung dengan menggunakan Metode Bina Marga Pd.T-10-2004-B (2004) tentang Prediksi Kebisingan Akibat Lalu Lintas dengan Model Calculation of Road Traffic Noise (CORTN, 1998). Dari hasil perhitungan dapat disimpulkan apakah tingkat kebisingan di kawasan RSIA Limijati dan Sekolah Taruna Bakti sudah memenuhi baku mutu yang diijinkan sesuai dengan kriteria bising untuk kawasan rumah sakit dan sekolah menurut Keputusan Menteri Negara Lingkungan Hidup No. 48/MENLH/11/1996 (1996) yaitu sebesar 55 dBA. Jika ternyata tingkat kebisingannya lebih besar dari baku mutu yang diijinkan, maka untuk menurunkannya perlu dilakukan mitigasi dampak kebisingan akibat lalu lintas jalan.

\section{METODOLOGI}

Metode pendekatan dalam prediksi kebisingan akibat lalu lintas disajikan dalam diagram alir pada Gambar 1 berikut ini: 


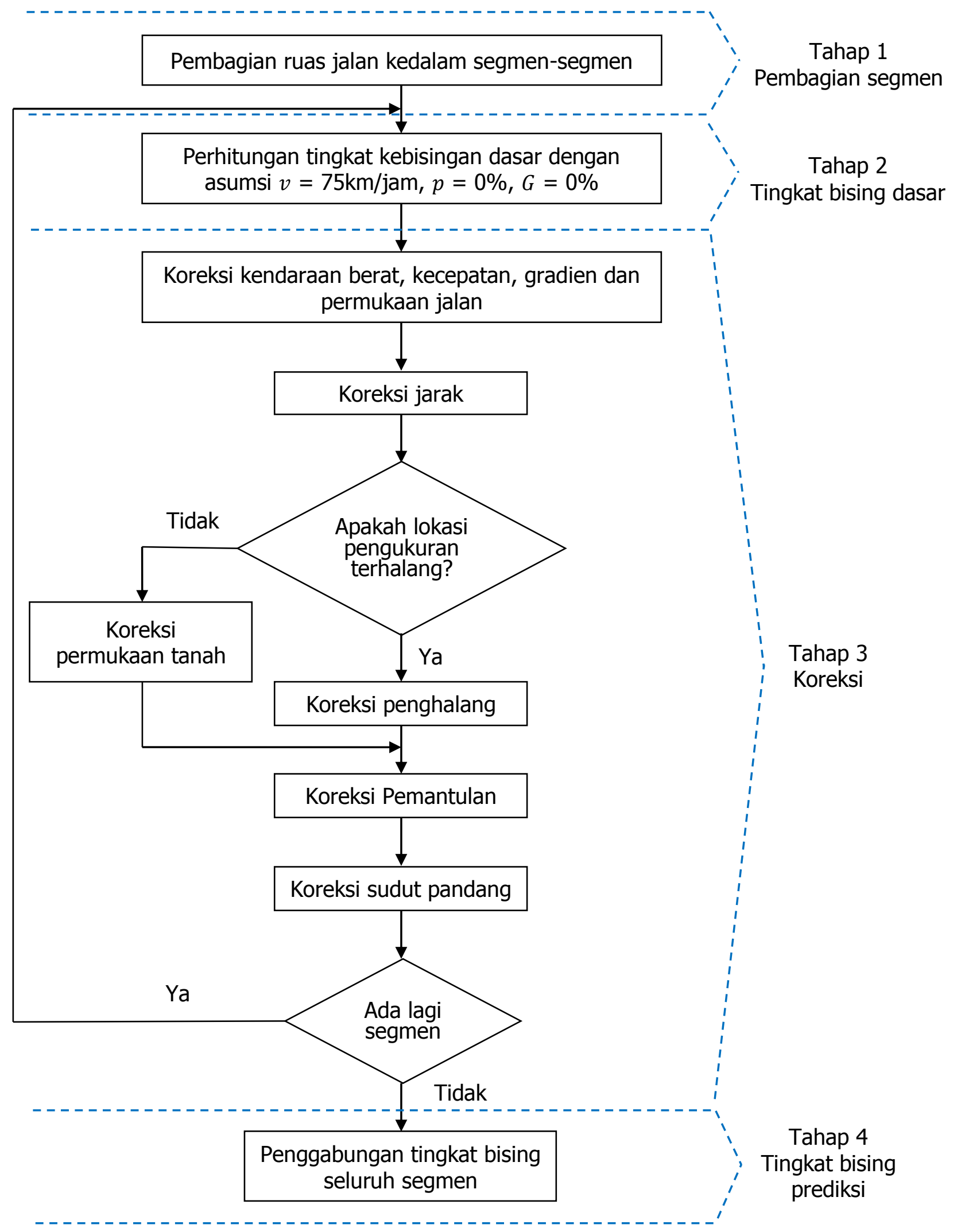

Gambar 1. Diagram alir Proses Prediksi Kebisingan (Sumber: Pd.T-10-2004-B, 2004)

Membagi ruas jalan ke dalam beberapa segmen sehingga akan diperoleh hasil prediksi tingkat bising yang akurat dan teliti. Pembagian dilakukan apabila secara visual kondisi fisik (geometrik dan lingkungan ruas jalan) berubah atau tidak homogen. Tingkat bising dasar 
selama 1 jam dihitung menggunakan Persamaan 1 dengan asumsi kecepatan rata-rata kendaraan $(v)=75 \mathrm{~km} / \mathrm{jam}$, jarak titik penerima $10 \mathrm{~m}$, proporsi kendaraan berat $(p)=0$ dan gradien $(G)=0$.

$$
\begin{aligned}
& L_{10}=42,2+10 \log q \\
& L_{e q}=L_{10}-3,0
\end{aligned}
$$

dengan:

$L_{10}=$ tingkat bising dasar selama 1 jam [dBA],

$L_{e q}=$ koreksi tingkat bising dasar selama 1 jam $[\mathrm{dBA}]$,

$q=$ total volume lalu lintas selama 1 jam.

Faktor koreksi kecepatan rata-rata dan persentase kendaraan berat dihitung menggunakan Persamaan 2, faktor koreksi gradien dihitung menggunakan Persamaan 3, dan faktor koreksi tingkat kebisingan berdasarkan jenis-jenis permukaan perkerasan disajikan dalam Tabel 1.

$$
\text { Faktor koreksi }=33 \log (v+40+500 / v)+10 \log (1+5 p / v)-68,8 \mathrm{dBA}
$$

dengan:

$v=$ kecepatan rata-rata $[\mathrm{km} / \mathrm{jam}]$,

$p=$ persentase kendaraan berat [\%].

$$
\text { Faktor koreksi }=0,3 \mathrm{G} \mathrm{dBA}
$$

dengan:

$G=$ gradien $[\%]$.

Tabel 1. Koreksi Permukaan Perkerasan

\begin{tabular}{ccc}
\hline No. & Uraian & Koreksi [dBA] \\
\hline 1 & Chip seal & $+3,0$ \\
\hline 2 & Beton semen portlan & $+1,0$ \\
\hline 3 & Beton aspal gradasi padat & $-1,0$ \\
\hline 4 & Beton aspal gradasi terbuka & $-5,0$ \\
\hline
\end{tabular}

Faktor koreksi jarak horizontal dari ujung sisi lajur jalan dan tinggi relatif antara titik penerima dengan posisi sumber bunyi efektif dihitung menggunakan Persamaan 4. Skema jarak titik penerima dan sumber bunyi disajikan dalam Gambar 2.

$$
\left.\begin{array}{l}
\text { Faktor koreksi }=-10 \log \left(d^{\prime} / 13,5\right) \\
d^{\prime}=\left[(d+3,5)^{2}+h^{2}\right]^{0,5}
\end{array}\right\}
$$

dengan:

$d^{\prime}=$ jarak kemiringan terdekat dari posisi sumber bunyi efektif [meter],

$d=$ jarak horizontal dari posisi sumber bunyi efektif [meter],

$h=$ tinggi titik penerima [meter]. 


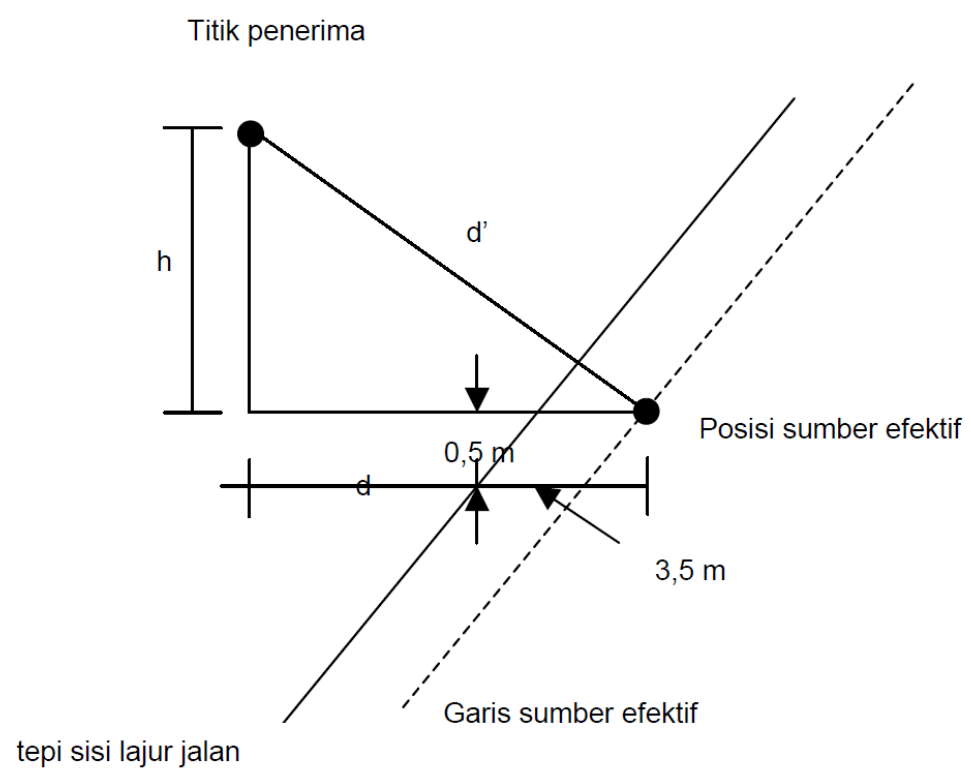

Gambar 2. Skema jarak titik penerima dan sumber bunyi

Koreksi penyerapan (absorpsi) tanah arah horizontal dari sisi lajur jalan terdekat $(d)$, tinggi rata-rata propagasi $(H)$, dan proporsi dari absorben tanah disajikan dalam Gambar 3.

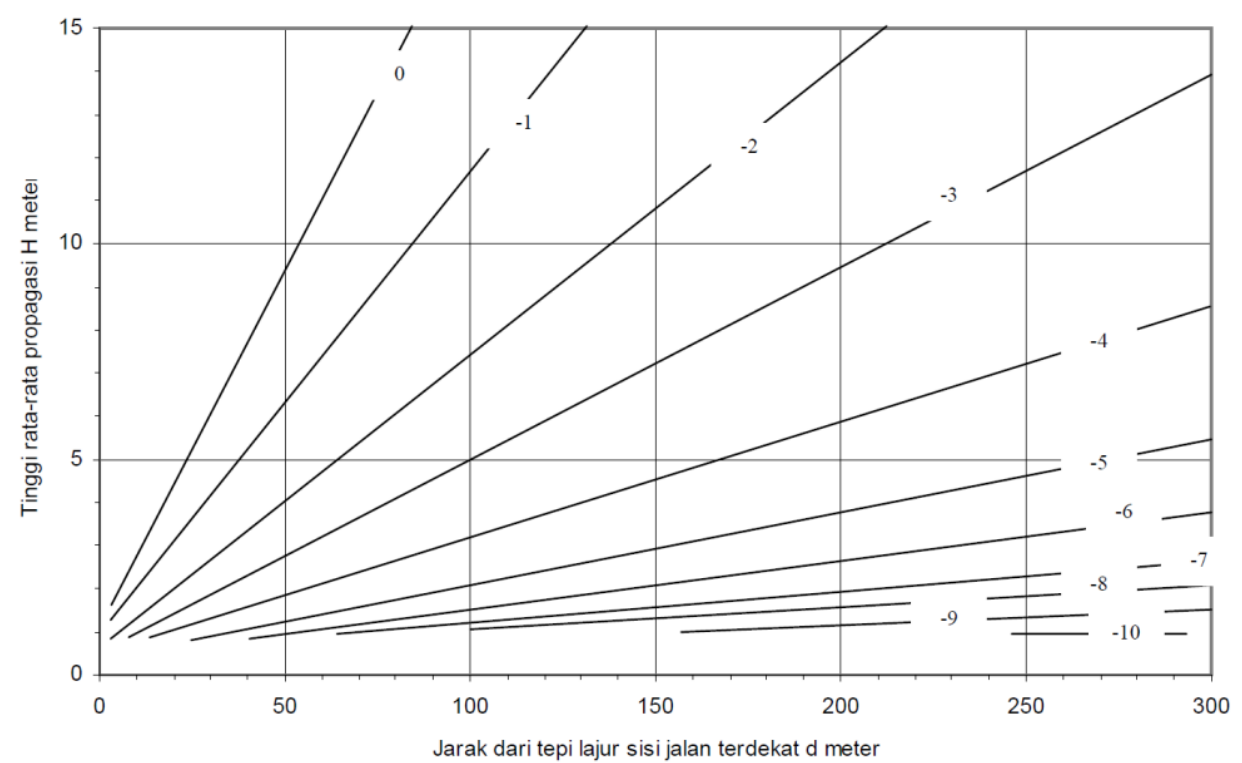

Gambar 3. Koreksi absorpsi tanah sebagai fungsi dari $d, H$, dan proporsi absorben tanah

Koreksi bangunan penghalang potensial sebagai fungsi dari perbedaan jarak berkas suara yang didifraksi terhadap berkas suara langsung pada zona bayangan dan zona terang disajikan dalam Gambar 4. Faktor koreksi tingkat kebisingan berdasarkan efek pemantulan disajikan dalam Tabel 2. Faktor koreksi sudut pandang jalan dihitung menggunakan Persamaan 5.

$$
\text { Faktor koreksi }=10 \log (\theta / 180) \mathrm{dBA}
$$

dengan:

$\theta=$ sudut pandang jalan [derajat]. 


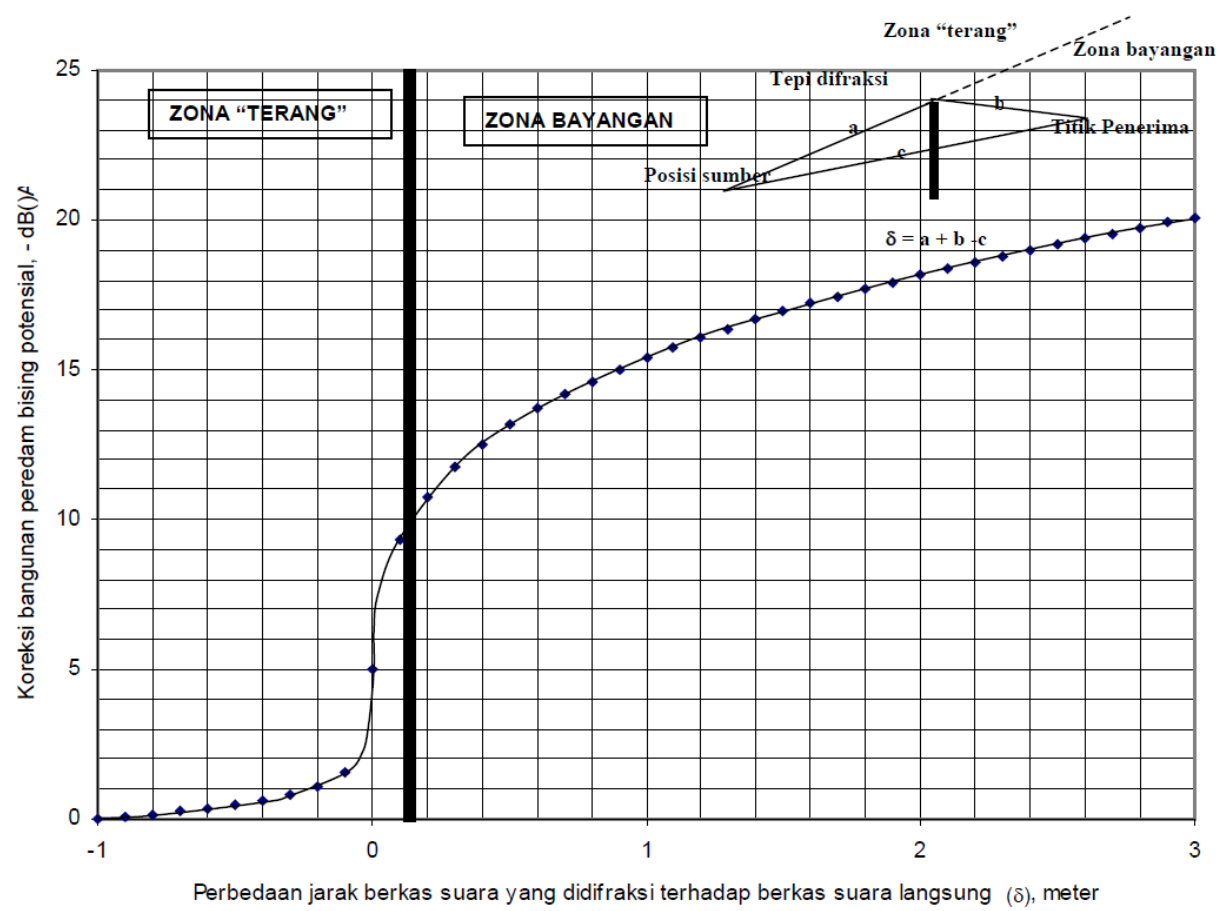

Gambar 4. Koreksi bangunan penghalang sebagai fungsi dari $\delta$ [meter]

Tabel 2. Faktor Koreksi Efek Pemantulan

\begin{tabular}{clc}
\hline No. & \multicolumn{1}{c}{ Uraian } & Koreksi [dBA)] \\
\hline 1 & Lapangan terbuka & 0 \\
\hline 2 & 1 meter di depan gedung & $+2,5$ \\
\hline 3 & Terdapat dinding menerus di samping kiri-kanan jalan & $+1,0$ \\
\hline
\end{tabular}

Penggabungan tingkat bising seluruh segmen untuk 2 tingkat bising $\left(L_{1}\right.$ dan $L_{2}$ ) dihitung menggunakan Persamaan 6, sedangkan untuk $n$ komponen tingkat bising $\left(L_{1}, L_{2}, \ldots, L_{n}\right)$ dihitung menggunakan Persamaan 7.

$$
\begin{aligned}
& L=10 \log [1+\operatorname{Antilog}(-\Delta / 10)] \mathrm{dBA} \\
& L=10 \log \left[\sum \operatorname{Antilog}(\ln / 10)\right] \mathrm{dBA}
\end{aligned}
$$

\section{HASIL DAN PEMBAHASAN}

Data volume lalu lintas dan persen kendaraan berat diperoleh dari hasil survai lapangan selama 1 jam sesuai dengan Pedoman Bina Marga No.016/T/BNKT/1990 (1990) tentang Tata Cara Pelaksanaan Survai Lalu Lintas. Data kecepatan kendaraan diperoleh dari hasil survai lapangan metode kecepatan setempat sesuai dengan Panduan Bina Marga No.001/T/BNKT/1990 (1990) tentang Survai dan Perhitungan Waktu Perjalanan Lalu Lintas. Data gradien dan jenis permukaan jalan diperoleh dari hasil survai lapangan sesuai dengan Tata Cara Bina Marga No.17/T/BNKT/1990 (1990) tentang Pelaksanaan Survai Inventarisasi Jalan dan Jembatan Kota. Perhitungan prediksi tingkat kebisingan disajikan dalam Tabel 3 sampai dengan Tabel 6. 
Tabel 3. Perhitungan Prediksi Tingkat Kebisingan di Kawasan RSIA Limijati (Weekdays)

\begin{tabular}{|c|c|c|c|c|}
\hline Tahap & Uraian & Parameter & Data Base & $\begin{array}{c}\text { Tingkat } \\
\text { Bising }[\mathrm{dBA}]\end{array}$ \\
\hline 1 & Pembagian segmen & - & - & - \\
\hline \multirow{4}{*}{2} & \multirow{4}{*}{ Tingkat bising dasar } & Volume lalu lintas 1 jam & 2.912 kendaraan & \multirow{4}{*}{76,84} \\
\hline & & Kecepatan kendaraan & 75 km/jam & \\
\hline & & Persen kendaraan berat & 0 & \\
\hline & & Gradien & 0 & \\
\hline TINGKA & T BISING DASAR & & & 76,84 \\
\hline \multirow{4}{*}{3} & \multirow{4}{*}{$\begin{array}{l}\text { Koreksi: Karakteristik lalu } \\
\text { lintas, geometrik, dan jenis } \\
\text { permukaan jalan }\end{array}$} & Persen kendaraan berat & $6,9 \%$ & \multirow{2}{*}{$-4,96$} \\
\hline & & Kecepatan kendaraan & $18 \mathrm{~km} / \mathrm{jam}$ & \\
\hline & & Gradien & 0 & 0,00 \\
\hline & & Jenis permukaan jalan & $\mathrm{AC}$ & $-1,00$ \\
\hline \multicolumn{2}{|c|}{ TINGKAT BISING DI SUMBER } & & & 70,88 \\
\hline \multirow{6}{*}{\multicolumn{2}{|c|}{ Propagasi }} & $\begin{array}{l}\text { Jarak penerima ke sumber } \\
\text { bunyi }\end{array}$ & $23,1 \mathrm{~m}$ & \multirow[t]{2}{*}{$-2,96$} \\
\hline & & Tinggi penerima & $2,5 \mathrm{~m}$ & \\
\hline & & Tinggi rata-rata propagasi & $2,25 \mathrm{~m}$ & \multirow[b]{2}{*}{$-1,80$} \\
\hline & & $\begin{array}{l}\text { Jarak penerima ke sumber } \\
\text { bunyi }\end{array}$ & $23,1 \mathrm{~m}$ & \\
\hline & & Tinggi bangunan peredam & $1,6 \mathrm{~m}$ & \multirow[b]{2}{*}{$-5,00$} \\
\hline & & $\begin{array}{l}\text { Jarak bangunan peredam ke } \\
\text { sumber bunyi }\end{array}$ & $3,1 \mathrm{~m}$ & \\
\hline \multirow{4}{*}{\multicolumn{2}{|c|}{ Sudut pandang }} & Dinding menerus & Ya & 1,00 \\
\hline & & Arah Barat & $48,29^{0}$ & $-5,71$ \\
\hline & & Arah Timur & $48,29^{0}$ & $-5,71$ \\
\hline & & Arah penghalang & $83,42^{0}$ & $-3,34$ \\
\hline \multicolumn{4}{|c|}{ Tingkat bising arah barat } & 61,40 \\
\hline \multicolumn{4}{|c|}{ Tingkat bising arah timur } & 61,40 \\
\hline \multicolumn{4}{|c|}{ Tingkat bising arah bangunan peredam bising } & 58,78 \\
\hline \multirow{3}{*}{4} & \multirow{3}{*}{$\begin{array}{l}\text { Penggabungan tingkat bising } \\
\text { prediksi seluruh segmen }\end{array}$} & LB & $61,40 \mathrm{dBA}$ & \multirow{3}{*}{65,46} \\
\hline & & LT & $61,40 \mathrm{dBA}$ & \\
\hline & & $\mathrm{LP}$ & $58,78 \mathrm{dBA}$ & \\
\hline \multicolumn{4}{|c|}{ TINGKAT BISING PREDIKSI, $L_{10} 1$ JAM } & 65,46 \\
\hline \multicolumn{4}{|c|}{ KONVERSI $L_{10} 1$ JAM TERHADAP $L_{e q} 1$ JAM } & 3,00 \\
\hline \multicolumn{4}{|c|}{ TINGKAT BISING PREDIKSI, $L_{e q} 1$ JAM } & 62,46 \\
\hline
\end{tabular}


Tabel 4. Perhitungan Prediksi Tingkat Kebisingan di Kawasan RSIA Limijati (Weekend)

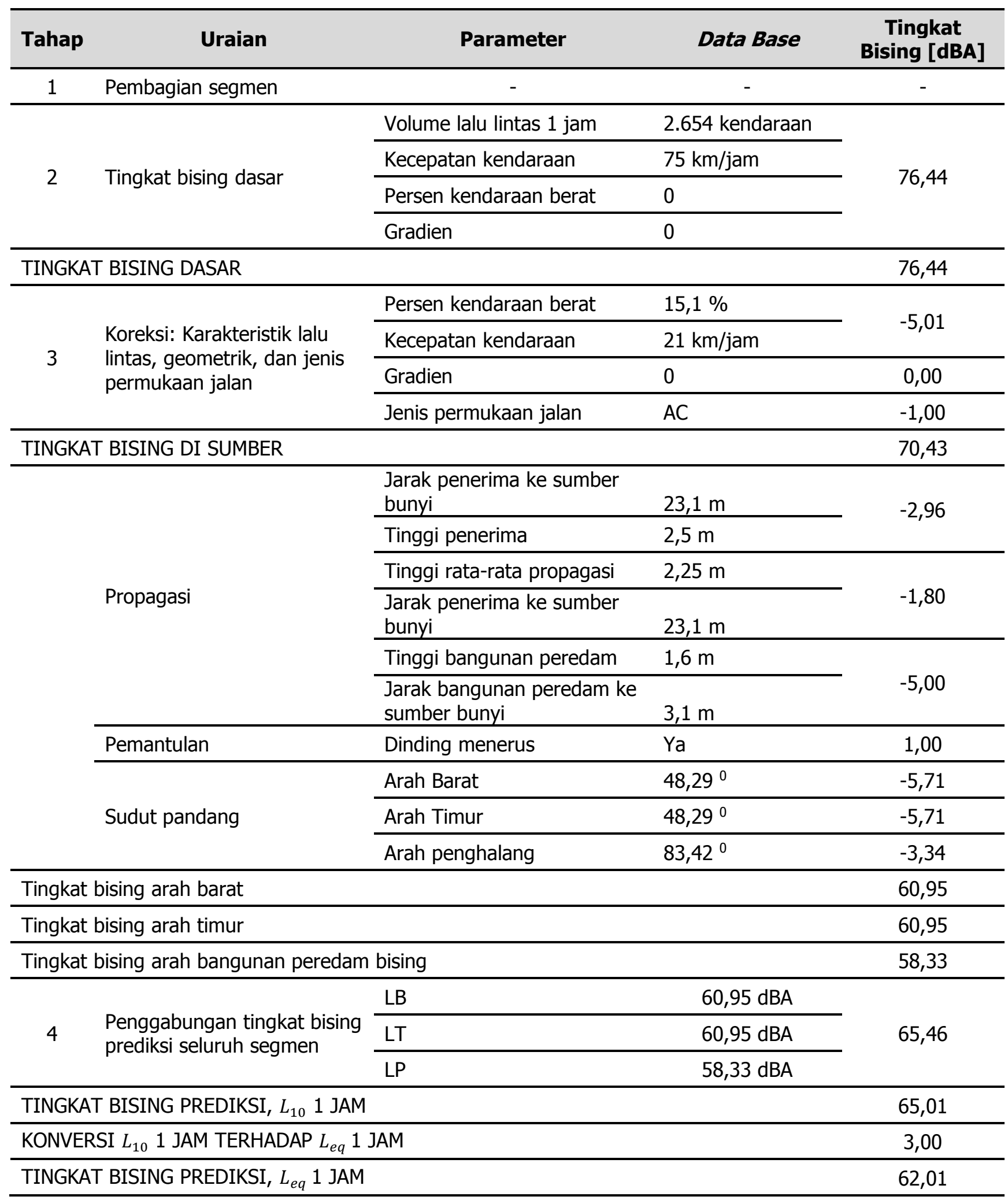


Tabel 5. Perhitungan Prediksi Tingkat Kebisingan di Kawasan Sekolah Taruna Bakti (Weekdays)

\begin{tabular}{|c|c|c|c|c|}
\hline Tahap & Uraian & Parameter & Data Base & $\begin{array}{c}\text { Tingkat } \\
\text { Bising [dBA] }\end{array}$ \\
\hline 1 & Pembagian segmen & - & - & - \\
\hline \multirow{4}{*}{2} & \multirow{4}{*}{ Tingkat bising dasar } & Volume lalu lintas 1 jam & 2.662 kendaraan & \multirow{4}{*}{76,45} \\
\hline & & Kecepatan kendaraan & $75 \mathrm{~km} / \mathrm{jam}$ & \\
\hline & & Persen kendaraan berat & 0 & \\
\hline & & Gradien & 0 & \\
\hline TINGKA $^{-1}$ & T BISING DASAR & & & 76,45 \\
\hline \multirow{4}{*}{3} & \multirow{4}{*}{$\begin{array}{l}\text { Koreksi: Karakteristik lalu } \\
\text { lintas, geometrik, dan jenis } \\
\text { permukaan jalan }\end{array}$} & Persen kendaraan berat & $11,3 \%$ & \multirow{2}{*}{$-4,80$} \\
\hline & & Kecepatan kendaraan & $17 \mathrm{~km} / \mathrm{jam}$ & \\
\hline & & Gradien & 0 & 0,00 \\
\hline & & Jenis permukaan jalan & $\mathrm{AC}$ & $-1,00$ \\
\hline \multicolumn{2}{|c|}{ TINGKAT BISING DI SUMBER } & & & 70,65 \\
\hline \multirow{6}{*}{\multicolumn{2}{|c|}{ Propagasi }} & $\begin{array}{l}\text { Jarak penerima ke sumber } \\
\text { bunyi }\end{array}$ & $15,6 \mathrm{~m}$ & \multirow{2}{*}{$-1,54$} \\
\hline & & Tinggi penerima & $2,5 \mathrm{~m}$ & \\
\hline & & Tinggi rata-rata propagasi & $2,25 \mathrm{~m}$ & \multirow[b]{2}{*}{$-1,05$} \\
\hline & & $\begin{array}{l}\text { Jarak penerima ke sumber } \\
\text { bunyi }\end{array}$ & $15,6 \mathrm{~m}$ & \\
\hline & & Tinggi bangunan peredam & $0 \mathrm{~m}$ & \multirow[b]{2}{*}{0,00} \\
\hline & & $\begin{array}{l}\text { Jarak bangunan peredam ke } \\
\text { sumber bunyi }\end{array}$ & $2,55 \mathrm{~m}$ & \\
\hline & Pemantulan & Dinding menerus & $\mathrm{Ya}$ & 1,00 \\
\hline \multirow{3}{*}{\multicolumn{2}{|c|}{ Sudut pandang }} & Arah Barat & $15,07^{0}$ & $-10,77$ \\
\hline & & Arah Timur & $15,07^{0}$ & $-10,77$ \\
\hline & & Arah penghalang & $149,85^{0}$ & $-0,80$ \\
\hline \multicolumn{4}{|c|}{ Tingkat bising arah barat } & 58,29 \\
\hline \multicolumn{4}{|c|}{ Tingkat bising arah timur } & 58,29 \\
\hline \multicolumn{4}{|c|}{ Tingkat bising arah bangunan peredam bising } & 68,26 \\
\hline \multirow{3}{*}{4} & \multirow{3}{*}{$\begin{array}{l}\text { Penggabungan tingkat bising } \\
\text { prediksi seluruh segmen }\end{array}$} & LB & $58,29 \mathrm{dBA}$ & \multirow{3}{*}{69,06} \\
\hline & & LT & $58,29 \mathrm{dBA}$ & \\
\hline & & LP & $68,26 \mathrm{dBA}$ & \\
\hline \multicolumn{4}{|c|}{ TINGKAT BISING PREDIKSI, $L_{10} 1 \mathrm{JAM}$} & 69,06 \\
\hline \multicolumn{4}{|c|}{ KONVERSI $L_{10} 1$ JAM TERHADAP $L_{e q} 1$ JAM } & 3,00 \\
\hline \multicolumn{4}{|c|}{ TINGKAT BISING PREDIKSI, $L_{e q} 1$ JAM } & 66,06 \\
\hline
\end{tabular}


Tabel 6. Perhitungan Prediksi Tingkat Kebisingan di Kawasan Sekolah Taruna Bakti (Weekend)

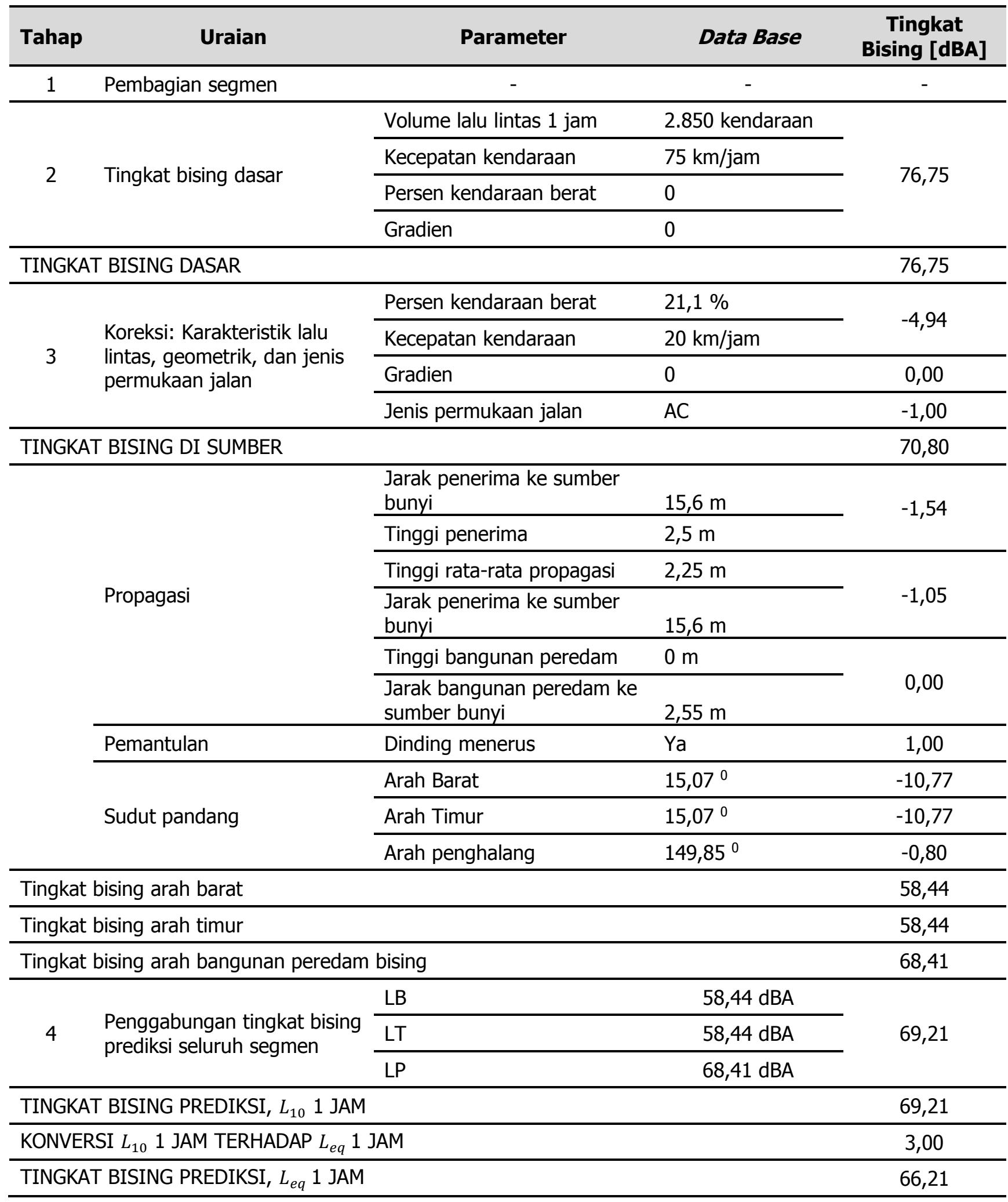


Tingkat kebisingan prediksi di kawasan Sekolah Taruna Bakti (66,06 dBA dan 66,21 dBA) lebih tinggi daripada di kawasan RSIA Limijati (62,46 dBA dan 62,01 dBA), hal ini dipengaruhi oleh: persen kendaraan berat, jarak penerima ke sumber bunyi, dan tinggi bangunan peredam.

\section{KESIMPULAN}

Berdasarkan hasil perhitungan prediksi tingkat kebisingan di kawasan RSIA Limijati diperoleh nilai kebisingan sebesar 62,46 dBA (weekdays) dan 62,01 dBA (weekend), sedangkan di kawasan Sekolah Taruna Bakti diperoleh nilai kebisingan sebesar 66,06 dBA (weekdays) dan 66,21 dBA (weekend). Dapat disimpulkan bahwa tingkat kebisingan di kawasan RSIA Limijati dan Sekolah Taruna Bakti sudah melebihi baku mutu yang diijinkan menurut Keputusan Menteri Negara Lingkungan Hidup No. 48/MENLH/11/1996 yaitu sebesar 55 dBA, sehingga untuk menurunkan tingkat kebisingan perlu dilakukan mitigasi dampak kebisingan akibat lalu lintas jalan. Penanganan pada sumber bising dapat dilakukan melalui beberapa hal, antara lain: pengaturan lalu lintas, pembatasan kendaraan berat, pengaturan kecepatan kendaraan, perbaikan kelandaian jalan, dan pemilihan jenis perkerasan jalan. Penanganan kebisingan pada jalur perambatan dapat dilakukan dengan pemasangan Bangunan Peredam Bising (BPB), berupa: penghalang dengan tanaman, timbunan tanah, dan penghalang buatan (beton, kayu, logam, kaca).

\section{DAFTAR RUJUKAN}

(1988). Calculation of Road Traffic Noise (CORTN). London: Department of Transport Welsh Office.

(1990). Panduan Survai dan Perhitungan Waktu Perjalanan Lalu Lintas, Manual No.001/T/BNKT/1990. Jakarta: Direktorat Jenderal Bina Marga.

(1990). Pedoman Tata Cara Pelaksanaan Survai Lalu Lintas, Manual

No.016/T/BNKT/1990. Jakarta: Direktorat Jenderal Bina Marga.

(1997). Manual Kapasitas Jalan Indonesia. Jakarta: Direktorat Jenderal Bina Marga.

(2004). Pd.T-10-2004-B tentang Prediksi Kebisingan Akibat Lalu Lintas. Jakarta:

Departemen Permukiman dan Prasarana Wilayah.

Griefahn B., Scheumer Kohrs-A, Scheumer R., Moehler U., Mehnert P. (2000). Physiological, subjective, and behavioural responses during sleep to noise from rail and road traffic. Noise and Health Inter-disciplinary International Journal, 3 (9), 59-73. Dipetik dari http://www.noiseandhealth.org/text.asp?2000/3/9/59/31769

Menteri Negara Lingkungan Hidup (1996). Kepmen No. KEP-48/MENLH/11/1996 tentang Baku Tingkat Kebisingan. Jakarta: Kementerian Negara Lingkungan Hidup.

Djalante (2010). Analisis Tingkat Kebisingan di Jalan Raya yang Menggunakan Alat Pemberi Isyarat Lalu Lintas (APIL). Jurnal SMARTek, 8(4), 280-300.

Suroto, W. (2010). Dampak Kebisingan Lalu Lintas terhadap Permukiman Kota. Surakarta. Journal of Rural and Development, Fakultas Teknik, Universitas Sebelas Maret, 1 (1), 5562.

Wardhana, W.A. (1999). Dampak Pencemaran Lingkungan. Yogyakarta: Andi Offset.

Widyantoro (2011). Pemetaan Sebaran Kebisingan akibat Aktifitas Transportasi dikaitkan dengan Tata Guna lahan di Jalan Arif Rachman Hakim Surabaya. Skripsi tidak dipublikasikan. Surabaya: Fakultas Teknik Sipil dan Perencanaan, Institut Teknologi Sepuluh Nopember. 